\title{
Analysis of the Causes of Accident in Construction Project
}

\author{
Shakil Ahmed \\ Former Student, Dept. of Building Engineering and Construction Management, KUET, Khulna, \\ Bangladesh \\ Email: ashakilmondol@gmail.com
}

\begin{abstract}
Bangladeshi construction industry suffers a lot of safety and accidental issues than other developing countries in the world. Among many of these, accident of construction project goes far beyond and shape a horrific figure of death for every year. The aims of this study is that analysis and discussion of causes of accident at construction project in Bangladesh. A widespread statistical data collection and data analysis take place to identify the causes and design the questionnaire. The questionnaire-based survey was used to elicit the attitude of four stakeholders as workers, owners, consultants, and contractors towards passive causes of fatal accident at construction site. These study also identify 77 passive causes under 14 major groups and ranked them based on Relative Importance Index (RII). The top 5 major group of causes are (1) Management related, (2) Consultant related, (3) Technology related, (4) Labour related and (5) Contractor related. The top 5 passive causes are: (1) Unaware of safety-related issue, (2) Lack of personal protective equipment, (3) Lack of safety eliminating/ avoiding design, (4) Unfit equipment, (5) Lack of knowledge and training on equipment.
\end{abstract}

Keywords: Accident; Construction Project; Causes; Bangladesh; RII Based Rank

\section{Introduction}

Construction industry is one of the most hazardous industries in the universe because of its unique nature. The construction projects are experiencing so many risks, uncertainties, complexities due to frequently happened accident in construction project [1]. Most of the developed countries trying to reduce the horrific damage and losses from construction accident by preventing, eliminate and bypass the possible accident in construction projects. But the developing countries are the extreme victim of construction accident because they have no strict regulation on construction safety and authorities and employee both don't aware of construction safety issue. [2]. Bangladesh has one of the most accident-prone construction industry among all the developing countries of the world. Bangladeshi construction industry experience more death, injury, physical damage of properties, risks and complexity than other countries in the world due to the horrific figure of occurring accident and it's fatality rate [3].

Every year, an average of 150 persons died and thousands of getting injured due to the accident in construction project in Bangladesh [4]. In 2017, Bangladeshi construction industry face about 179 person died due to accident and in 2016 and 2015 the figure of death is 145 and 172 persons [5]. Just in 2017, in Bangladesh construction accident take life 15 time's higher than Singapore, 6 times higher than Britain, 8 times greater than Japan and 8 times higher than North Carolina State, USA [6-9]. This scenario of accident means that how the vulnerable level of safety exist and practice in Bangladeshi construction project. High officials from OSHE Bangladesh said "accident in construction project is the topmost serious issue for Bangladeshi construction. It is considered as the main barrier of innovation and development of construction industry in Bangladesh. It brings so many complexities in many ways. It is bad, it is really bad for Bangladeshi construction industry". Construction accident is the mother of others many problems and 
complexities in construction project. Failure of adoption and assurance of construction safety against accident in construction project have various affected the project negatively. It is the main cause of project delay $[10,11]$, affecting the quality of construction work [12-14], decreasing the labor productivity [15, 16], cost overrun of the project [17, 18], arising dispute between stakeholders [19], affecting the psychology of worker negatively [20]. It shows a clear picture that the Bangladeshi industry is not going with the good condition due to many issues but the prime one is accident in construction projects. Experts said that in Bangladesh there are $80 \%$ construction project experience injuries and death from accidents. The consequences of this accidents go far beyond the particular construction project.

Today, it is a basic right of every worker to work a safe and accident-free workplace. Other countries in the world started working to reduce the accident rate in construction industry and they have shown success in various ways to reduce or even eliminate accident in construction projects. Bangladesh has to work with this issue seriously to reduce the accident rate and improve the construction industry with modern technologies and strategies. Numerous examinations have demonstrated that a fairly large percentage of fatal accident at construction project could have been eliminated, reduced, or avoided if straightforward safety systems were applied at the sites and the employees were trained and made aware of the safety hazards present in the particular site (Zhang, Teaser, Lee, Eastman, \& Venugopal, 2013). A comprehensive safety program has to be designed to prevent and control accident at construction project based on the cause which responsible for the accident. If the real scenario of behind the accident comes to light, it will be easier for the authority to take effective necessary steps to improve the safety program and reduce the accident rate in Bangladesh. For this, at first it is necessary to find out the reason behind construction accident in Bangladesh. To assist the authority and to improve the accident scenario, the main purpose of this study is to investigate, identify and analyze the causes of accident in construction project in Bangladesh. This study may help the authorities and project executives to know and understand about the causes of accident in construction project in Bangladesh. It will also offer some suggestions which can play a vital role to decrease the accident rate and assist the stakeholders to complete construction project successfully with current flow.

\section{Background Study}

Construction industry has encountered the highest number of fatal accidents among all other industries in the world [21]. Thus, studying the causes of accident in construction projects has gained increasing importance to researchers in the recent years although there is no research conducted before on the topic for Bangladeshi construction industry. Therefore, many studies have been conducted in this area of research in different parts of the world. Few of them are discussed below.

Cheng and $\mathrm{Wu}$ [22] analyzed the characteristics of construction accidents in small projects in Taiwan using descriptive statistics and correlation coefficients. They discovered that the most critical cause of accidents was careless acts about the implementation of safety measures at project sites, followed by insufficient safety training for novice workers, absence of competent health and safety professionals, proper attention from the authority to safety issue and lack of safety awareness. In Malaysia, Abdul Rahim Abdul Hamid [23] identified a good number of causes of accidents at his research. The main causes of accidents are revealed such as unsafe equipment, job sites condition, unique nature of industry, unsafe method, management, poor safety policies, personal protective equipment (PPE), work at high elevation, poor site management and equipment failure. Priyadarshani et al. [24] developed a safety assessment framework for construction industry in Sri Lanka. According to their study, lack of commitment of management, lack of safety measure, negligence of individuals to respond to proper safety practices and unskilled worker were the most important factors leading to accidents at sites. Work at high elevation, poor site management, equipment failure, lack of skill and experience of executive and lack of worker training are the important causes which work behind construction accident in United Arab Emirates [25]. Uduakobonge et al. [26] revealed the major causes of construction accident in Nigeria and these are lack of safety measure while handling materials/objects and lifting materials/objects, slips, trip on object, operating damaged equipment, 
struck by moving objects, struck by moving machine/equipment, caving in of excavations and fall from height. Haslam et al. [27] illustrate that accidents occur as a result of the poor interaction between workers or work-team (worker behavior), workplace (poor housekeeping and material storing) and materials/equipment (PPE) that originate due to insufficiency in the construction design and process, project and risk management, customer/owner and economic effects, or safety education and training. Ogwueleka [28] conduct a comprehensive literature review to analyze the causes of construction accident and pointed out as the most influencing factors are management commitment, safety awareness of top management/ project managers, errors in judgment or carelessness, expert knowledge or training, poor machinery and safety management practices/ procedure/ review.

\section{Methodology}

Mixed method enriches the validity and reliability of the results of a study and the comprehension of the studied phenomenon while enabling new dimensions to the study to emerge. The mixed research approach was used in this study considering the nature of the research problem. This study conducted through a comprehensive literature review and expert opinion to identify the causes and design the questionnaire and a comprehensive questionnaire survey to rank the causes.

\subsection{Questionnaire Design}

To identify the causes of construction accident in Bangladesh a deep and broad literature review is conducted for sorting out a rough factors list. After that an open discussion was happened with an experts panel (the panel consist of government officials, high officials from NGO, executive of labour organization, experienced contractor, engineers, project managers, university professors and university students) to identify the causes which are reasonable for the aspect of Bangladeshi construction industry. A total of 71 causes are identified under 14 major groups for the construction accident in Bangladesh. The 14 major groups of causes are (1) Project related, (2) Site Condition related, (3) Contract related, (4) Design related, (5) Material related, (6) Cost \& Time related, (7) Consultant related, (8) Contractor related, (9) Labour related , (10) Owner related, (11) Equipment and Tools related, (12) Management related, (13) Technology related, and (14) External related.

A questionnaire survey was used to elicit the attitude of owners, consultants, labours and contractors towards the factors influencing the accidents in construction projects in Bangladesh. The questionnaire was designed with two major part. Part I is about the background information of the respondents. And in part II the respondents were asked to evaluate, based on their local experience the level of importance of each one of the identified 71 factors under 14 major groups that influence the accident on a seven-point Likert Scale as: (1) strongly disagree, (2) disagree, (3) moderately disagree, (4) neutral, (5) moderately agree, (6) agree and (7) strongly agree.

\subsection{Data Collection}

The necessary data were collected through the questionnaire survey among the construction workers by visiting construction sites, labor unions, construction companies, and government agencies and so on. 147 questionnaires were distributed as follows: 44 to workers, 27 to owners, 41 to consultants and 35 to contractors. 108 questionnaires $(73.5 \%)$ were returned as follows: 32 from workers, 23 from owners, 28 from consultants, and 25 from contractors as respondents.

\subsection{Data Analysis}

The Relative Important Index (RII) is used for the determination of the rank between the 71 causes. The relative importance index method (RII) indicates herein to determine owners, consultants, labours and contractors perceptions of the relative importance of the identified influencing factors. An equation express below is used to determine the value of RII for each factor. Equation 1 is used in many research for the determination of impotency and relative rank [[29], [30], [31]]. 


$$
\text { Relative Importance Index }(\mathrm{RII})=\frac{\sum W}{A \times N}
$$

In the above (1) equation ' $\mathrm{W}$ ' is the weighting given to each factor by the respondents (ranging from 1 to 7), ' $A$ ' is the highest weight (i.e. 7 in this case), and ' $N$ ' is the total number of respondents in this study (i.e. 108 in this study).

\section{Results Analyis}

In this study there 77 causes under 14 major causes are identified. A huge amount of fatal accident at construction site take place in Bangladesh. And a tremendous amount of people died in the accident in construction projects in Bangladesh. In Bangladesh, behind the huge amount of accident, these 77 causes are responsible directly and indirectly in any ways at all. But which one is the highest contributor than others and what is the level of contribution than others to influencing accident in construction project? This question is answered by the RII of each cause and the RII based rank. The seventy-seven (77) causes of fatal accident at construction site are not as same as for all respondent groups. The different respondent group expressed different type of attitude toward the causes. So their giving rank for the causes of accident are not same. For revealing the actual scenario of accident to various stakeholders of construction project it is essential to know the opinion of all groups of respondents toward each cause of accident. Table 2 shows the Summary of RII and RII based rank of each causes for four (4) respondent group worker, contractor, owner and consultant.

Table 2: Summary of RII and rank of causes of accident in construction project

\begin{tabular}{|c|c|c|c|c|}
\hline $\begin{array}{l}\text { Major } \\
\text { Group }\end{array}$ & Causes of Accident & RII & $\begin{array}{c}\text { Rank } \\
\text { (overall) }\end{array}$ & $\begin{array}{c}\text { Rank } \\
\text { (among } \\
\text { the group) }\end{array}$ \\
\hline \multirow{6}{*}{ 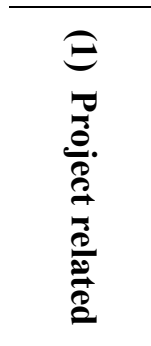 } & Value of project & 0.581 & 43 & 3 \\
\hline & Poor Planning/ scheduling of project & 0.567 & 48 & 4 \\
\hline & Very tight project schedule & 0.606 & 26 & 2 \\
\hline & Type and nature of project & 0.625 & 19 & 1 \\
\hline & Social and communal involvement of project & 0.508 & 71 & 5 \\
\hline & Financial body (Government or private) & 0.456 & 77 & 6 \\
\hline \multirow{4}{*}{ 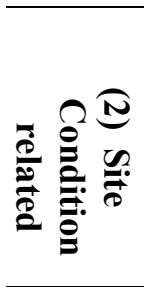 } & $\begin{array}{l}\text { Project site conditions (exclude equipment, } \\
\text { materials, weather) }\end{array}$ & 0.567 & 49 & 3 \\
\hline & Project site layout/space & 0.565 & 51 & 4 \\
\hline & $\begin{array}{l}\text { Project working environment } \\
\text { (light/noise/hot/cold/wet) }\end{array}$ & 0.594 & 33 & 2 \\
\hline & Poor housekeeping & 0.609 & 23 & 1 \\
\hline \multirow{5}{*}{ 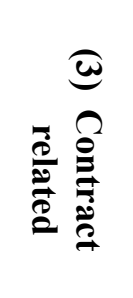 } & Not-strict operation procedures in contract & 0.644 & 12 & 1 \\
\hline & Coordination between project participants & 0.534 & 70 & 5 \\
\hline & Lack of Management commitment in contract & 0.557 & 54 & 3 \\
\hline & Type of awarding contract & 0.543 & 66 & 4 \\
\hline & Unclear contract conditions on safety issue & 0.585 & 40 & 2 \\
\hline
\end{tabular}




\begin{tabular}{|c|c|c|c|c|}
\hline \multirow{4}{*}{ 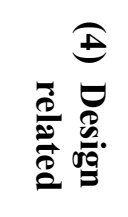 } & Design is not constructible & 0.548 & 61 & 3 \\
\hline & Incomplete and inconsistency of design document & 0.545 & 65 & 4 \\
\hline & Safety is not consider when design & 0.632 & 17 & 2 \\
\hline & Lack of safety eliminating/ avoiding design & 0.669 & 3 & 1 \\
\hline \multirow{5}{*}{ 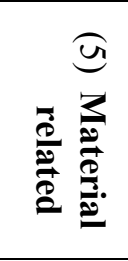 } & Lack of protection in material carrying & 0.479 & 76 & 5 \\
\hline & Lack of protection in material storage & 0.633 & 15 & 1 \\
\hline & Working with toxic/ hazardous materials & 0.558 & 53 & 3 \\
\hline & Hazard during transportation & 0.603 & 28 & 2 \\
\hline & Lack of knowledge about construction materials & 0.556 & 55 & 4 \\
\hline \multirow{3}{*}{ 当 \& ? } & Cost overrun reduce the safety cost & 0.494 & 73 & 3 \\
\hline & Schedule delays and rework in construction project & 0.547 & 62 & 2 \\
\hline & Short time assign to worker & 0.596 & 31 & 1 \\
\hline \multirow{6}{*}{ 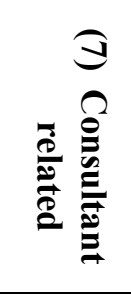 } & Lack of Management/ leadership skills & 0.595 & 32 & 3 \\
\hline & Lack of knowledge and experience & 0.540 & 68 & 6 \\
\hline & Unaware of construction safety & 0.645 & 11 & 2 \\
\hline & irregular investigation & 0.659 & 6 & 1 \\
\hline & Flexible to contractor/worker on safety issue & 0.551 & 60 & 5 \\
\hline & No interest to change the safety culture & 0.593 & 34 & 4 \\
\hline \multirow{6}{*}{ 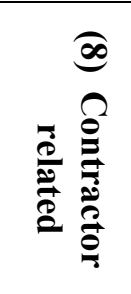 } & Inaccurate or incomplete schedule & 0.579 & 44 & 4 \\
\hline & Unaware of safety related issue & 0.686 & 1 & 1 \\
\hline & Unwilling to spend safety related cost & 0.642 & 13 & 2 \\
\hline & Lack of skill and experience of site staff & 0.536 & 69 & 6 \\
\hline & Violating BNBC code/ Bangladesh labour law & 0.589 & 38 & 3 \\
\hline & Reckless action of contractor & 0.574 & 46 & 5 \\
\hline \multirow{9}{*}{ 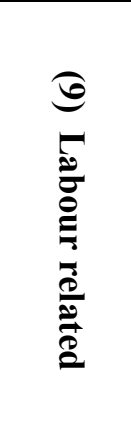 } & Lack of collaboration among labours & 0.583 & 41 & 6 \\
\hline & Lack of personal protective equipment & 0.674 & 2 & 1 \\
\hline & Unskilled labours & 0.652 & 10 & 3 \\
\hline & Worker empowerment to make decision & 0.560 & 52 & 7 \\
\hline & Poor of education of labourers & 0.555 & 56 & 8 \\
\hline & Lack of Expertise, knowledge or training & 0.657 & 8 & 2 \\
\hline & Interference with others role & 0.543 & 67 & 9 \\
\hline & Over time for labours & 0.605 & 27 & 5 \\
\hline & Behaviour of worker & 0.610 & 22 & 4 \\
\hline \multirow{5}{*}{ 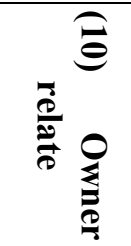 } & Unwilling to pay extra cost for safety & 0.655 & 9 & 1 \\
\hline & Owner's interference on schedule and process & 0.500 & 72 & 4 \\
\hline & Owner's expectations variation & 0.483 & 74 & 5 \\
\hline & Lack of owner's emphasis on safety & 0.546 & 64 & 3 \\
\hline & owner's late response ( decision making) & 0.546 & 63 & 2 \\
\hline
\end{tabular}




\begin{tabular}{|c|c|c|c|c|}
\hline \multirow{6}{*}{ 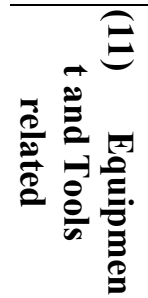 } & Unfit equipment & 0.666 & 4 & 3 \\
\hline & Poor equipment maintenance & 0.632 & 16 & 6 \\
\hline & Unused of modern equipment & 0.607 & 24 & 5 \\
\hline & High cost of advanced equipment and tools & 0.623 & 20 & 4 \\
\hline & Improper use of equipment & 0.630 & 18 & 2 \\
\hline & Lack of knowledge and training on equipment & 0.665 & 5 & 1 \\
\hline \multirow{3}{*}{$\widehat{\mathbb{N}}$} & Lack of effective Project supervision & 0.607 & 25 & 2 \\
\hline & Lack of effective Communication & 0.588 & 39 & 6 \\
\hline & Inadequate safety policy & 0.658 & 7 & 1 \\
\hline \multirow{5}{*}{ 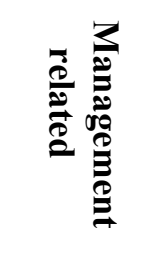 } & Improper auditing system & 0.591 & 36 & 5 \\
\hline & Poor Organization structure & 0.582 & 42 & 7 \\
\hline & Lack of information flow & 0.591 & 35 & 4 \\
\hline & Lack of technique guide & 0.553 & 58 & 8 \\
\hline & Lack of teamwork & 0.598 & 30 & 3 \\
\hline \multirow{6}{*}{ 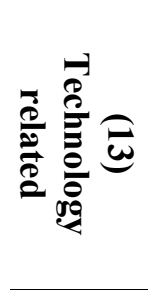 } & Unused of safety control system & 0.636 & 14 & 1 \\
\hline & Unused of schedule system & 0.481 & 75 & 6 \\
\hline & Unaware to advanced technology for safety & 0.568 & 47 & 4 \\
\hline & Lack of implementation of BIM & 0.612 & 21 & 2 \\
\hline & Lack of innovation technology & 0.575 & 45 & 3 \\
\hline & Lack of implement safety control sensor technology & 0.551 & 59 & 5 \\
\hline \multirow{4}{*}{ 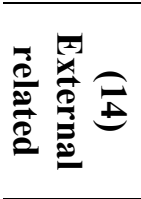 } & Act of God & 0.555 & 57 & 4 \\
\hline & External obstacle/ barrier & 0.566 & 50 & 3 \\
\hline & Nature of construction & 0.590 & 37 & 2 \\
\hline & Bad weather & 0.601 & 29 & 1 \\
\hline
\end{tabular}

\subsection{High Ranked Causes}

There are some causes are identified in this study which is very influencing to occurring accident at construction project in Bangladesh. And these accident bring out a huge amount death for each year. In Table 3 top twenty (20) high ranked causes from different major group of causes are shown based on their RII value for all groups.

Table 3: Summary of top high ranked causes of accident for all groups

\begin{tabular}{llcc}
\hline Passive Causes & Major Group & RII & Rank \\
\hline Unaware of safety related issue & Contractor & 0.686 & $\mathbf{1}$ \\
\hline Lack of personal protective equipment & Labour & 0.674 & $\mathbf{2}$ \\
\hline Lack of safety eliminating/ avoiding design & Design & 0.669 & $\mathbf{3}$ \\
\hline Unfit equipment & Equipment and Tools & 0.666 & $\mathbf{4}$ \\
\hline Lack of knowledge and training on equipment & Equipment and Tools & 0.665 & $\mathbf{5}$ \\
\hline Irregular investigation & Consultant & 0.659 & $\mathbf{6}$ \\
\hline Inadequate safety policy & Management & 0.658 & $\mathbf{7}$ \\
\hline Lack of Expertise, knowledge or training & Labour & 0.657 & $\mathbf{8}$ \\
\hline
\end{tabular}




\begin{tabular}{lllc}
\hline Unwilling to pay extra cost for safety & Owner & 0.655 & $\mathbf{9}$ \\
\hline Unskilled labours & Labour & 0.652 & $\mathbf{1 0}$ \\
\hline
\end{tabular}

Table 3 indicates the top most crucial cause of construction fatal accident in Bangladesh is contractor unaware of safety related issue $(\mathrm{RII}=0.686)$. The second highest cause is lack of personal protective equipment of worker $(\mathrm{RII}=0.674)$. Third and fourth highest ranked causes are lack of safety eliminating/ avoiding design $(\mathrm{RII}=0.669)$ and unfit equipment use in the construction work $(\mathrm{RII}=0.666)$. The fifth, sixth and seventh top ranked causes are lack of knowledge and training on equipment (RII $=0.665)$, irregular investigation by consultant $(\mathrm{RII}=0.659)$ and inadequate safety policy adopted by management $(\mathrm{RII}=0.658)$. Another causes in top ten (10) are lack of expertise, knowledge or training of worker (RII $=0.657)$, owner unwilling to pay extra cost for safety $(\mathrm{RII}=0.655)$ and Unskilled labour $(\mathrm{RII}=0.652)$.

Consultant unaware of construction safety $(\mathrm{RII}=0.645)$, not-strict operation procedures in contract $(\mathrm{RII}=0.644)$, contractor unwilling to spend safety related cost $(\mathrm{RII}=0.642)$, unused of safety control Technology $(R I I=0.636)$ and lack of protection in material storage causes $(R I I=0.652)$ are also within the top fifteen (15) cause of fatal accident at construction site in Bangladesh.

\subsection{Low Ranked Causes}

Among the initially identified 77 causes of accidents, some are determined as a very low contributor for the influencing accident on construction project in Bangladesh. These very low ranked causes have scattered in table 2 but Table 4 shows the low ranked causes as ascending order with their respective major group of causes according to Relative Important Index (RII).

Table 4: Summary of top low ranked causes of accident on construction project

\begin{tabular}{lllc}
\hline Causes & Major group & RII & Rank \\
\hline Financial body (WB, ADP, Government or private) & Project & 0.456 & 77 \\
\hline Lack of protection in material carrying & Material & 0.479 & 76 \\
\hline Unused of schedule system & Technology & 0.481 & 75 \\
\hline Owner's expectations variation & Owner & 0.483 & 74 \\
\hline Cost overrun reduce the safety cost & Cost \& Time & 0.494 & 73 \\
\hline Owner's interference on schedule and process & Owner & 0.500 & 72 \\
\hline Social and communal involvement of project & Project & 0.508 & 71 \\
\hline Coordination between project participants & Contract & 0.534 & 70 \\
\hline Lack of skill and experience of site staff & Contractor & 0.536 & 69 \\
\hline Lack of knowledge and experience & Consultant & 0.540 & 68 \\
\hline
\end{tabular}

Table 4 indicates the topmost low ranked, $77^{\text {th }}$ factors of construction accident in Bangladesh is financial bodies decision and attitude (WB, ADP, Government or private) with the RII $=0.456$. The second lowest, $76^{\text {th }}$ cause is lack of protection in material carrying $(\mathrm{RII}=0.479)$. Third and fourth lowest ranked causes are unused of schedule system $(\mathrm{RII}=0.481)$ and owner's expectations variation $(\mathrm{RII}=0.483)$. The fifth, sixth and seventh lowest ranked causes mean $73^{\text {th }}, 72^{\text {th }}$ and $71^{\text {th }}$ causes are cost overrun reduce the safety cost $(\mathrm{RII}=0.494)$, owner's interference on schedule and process $(\mathrm{RII}=0.500)$ and social and communal involvement of project $(\mathrm{RII}=0.508)$. Rest of the top ten $(10)$ means $70^{\text {th }}, 69^{\text {th }}$ and $68^{\text {th }}$ causes are coordination between project participants $(\mathrm{RII}=0.534)$, lack of skill and experience of site staff $(\mathrm{RII}=0.536)$ and lack of knowledge and experience of consultant $(\mathrm{RII}=0.540)$.

\subsection{High Ranked Causes for All Respondent Groups}


As the respondent groups show the different attitude toward the causes of accident. So the rank for the causes of fatal accident at construction site in Bangladesh are not same for each respondent groups, Table 5.1 and Table 5.2 shows the high ranked causes for each respondents groups. Table 5.1 represents the high raked causes for the respondent groups of the worker and contractor and Table 5.2 represents the high raked causes for the respondent groups of the consultant and owner.

Table 5.1: Summary of high ranked causes for Worker and Contractor groups

\begin{tabular}{cll|ll}
\hline \multirow{2}{*}{ Rank } & \multicolumn{2}{c|}{ Worker group } & \multicolumn{2}{c}{ Contractor group } \\
\cline { 2 - 5 } & Causes of Accident & $\begin{array}{l}\text { Major } \\
\text { Group }\end{array}$ & Causes of Accident & Major Group \\
\hline $\mathbf{1}$ & $\begin{array}{l}\text { Not-strict operation } \\
\text { procedures in contract }\end{array}$ & Contract & $\begin{array}{l}\text { Lack of personal protective } \\
\text { equipment }\end{array}$ & Labour \\
\hline $\mathbf{2}$ & $\begin{array}{l}\text { Lack of safety eliminating/ } \\
\text { avoiding design }\end{array}$ & Design & $\begin{array}{l}\text { Lack of knowledge and } \\
\text { training on equipment }\end{array}$ & $\begin{array}{l}\text { Equipment } \\
\text { and Tools }\end{array}$ \\
\hline $\mathbf{3}$ & $\begin{array}{l}\text { No interest to change the } \\
\text { safety culture }\end{array}$ & Consultant & $\begin{array}{l}\text { Violating BNBC code/ } \\
\text { Bangladesh labour law }\end{array}$ & Contractor \\
\hline $\mathbf{4}$ & Unskilled labours & Labour & Inadequate safety policy & Management \\
\hline $\mathbf{5}$ & $\begin{array}{l}\text { Unwilling to spend safety } \\
\text { related cost }\end{array}$ & Contractor & $\begin{array}{l}\text { Unwilling to pay extra cost } \\
\text { for safety }\end{array}$ & Owner \\
\hline $\mathbf{6}$ & irregular investigation & Consultant & Unfit equipment & Equipment \\
\hline $\mathbf{7}$ & $\begin{array}{l}\text { Lack of Expertise, knowledge } \\
\text { or training }\end{array}$ & Labour & $\begin{array}{l}\text { Not-strict operation } \\
\text { procedures in contract }\end{array}$ & Contract \\
\hline $\mathbf{8}$ & Unfit equipment & $\begin{array}{l}\text { Equipment } \\
\text { and Tools }\end{array}$ & $\begin{array}{l}\text { High cost of advanced } \\
\text { equipment and tools }\end{array}$ & $\begin{array}{l}\text { Equipment } \\
\text { and Tools }\end{array}$ \\
\hline $\mathbf{9}$ & $\begin{array}{l}\text { Lack of knowledge and } \\
\text { experience }\end{array}$ & Consultant & $\begin{array}{l}\text { Lack of Management/ } \\
\text { leadership skills }\end{array}$ & Consultant \\
\hline $\mathbf{1 0}$ & $\begin{array}{l}\text { Unaware of safety related } \\
\text { issue }\end{array}$ & Contractor & $\begin{array}{l}\text { Unaware of safety related } \\
\text { issue }\end{array}$ & Contractor \\
\hline
\end{tabular}

From Table 5.1, it is shown that the highest ranked causes for worker group are not-strict operation procedures in the contract. Lack of safety eliminating/ avoiding design, no interest to change the safety culture, unskilled labours, and unwilling to spend safety related cost are also in the top five causes for the worker respondent group. The contractor group determines that, lack of personal protective equipment of labor is the topmost crucial causes of influencing fatal accident at construction site. The other most important contributor of influencing accident for the contractor group is lack of knowledge and training on equipment, violating BNBC code/ Bangladesh labour law, inadequate safety policy, unwilling to pay extra cost for safety and unfit equipment.

Table 5.2: Summary of high ranked causes for Owner and Consultant groups

\begin{tabular}{cll|ll}
\hline \multirow{2}{*}{ Rank } & \multicolumn{2}{c|}{ Owner group } & \multicolumn{2}{c}{ Consultant group } \\
\cline { 2 - 5 } & Causes of Accident & Major Group & Causes of Accident & $\begin{array}{l}\text { Major } \\
\text { Group }\end{array}$ \\
\hline $\mathbf{1}$ & Inadequate safety policy & Management & Unfit equipment & $\begin{array}{l}\text { Equipment } \\
\text { and Tools }\end{array}$ \\
\hline $\mathbf{2}$ & Unfit equipment & $\begin{array}{l}\text { Equipment } \\
\text { and Tools }\end{array}$ & $\begin{array}{l}\text { Unaware of safety related } \\
\text { issue }\end{array}$ & Contractor \\
\hline $\mathbf{3}$ & Lack of teamwork & Management & $\begin{array}{l}\text { Lack of knowledge and } \\
\text { training on equipment }\end{array}$ & $\begin{array}{l}\text { Equipment } \\
\text { and Tools }\end{array}$ \\
\hline
\end{tabular}




\begin{tabular}{cll|ll}
\hline $\mathbf{4}$ & $\begin{array}{l}\text { Not-strict operation } \\
\text { procedures in contract }\end{array}$ & Contract & Improper auditing system & Management \\
\hline $\mathbf{5}$ & $\begin{array}{l}\text { Unaware of safety related } \\
\text { issue }\end{array}$ & Contractor & $\begin{array}{l}\text { Safety is not consider when } \\
\text { design }\end{array}$ & Design \\
\hline $\mathbf{6}$ & $\begin{array}{l}\text { Lack of personal protective } \\
\text { equipment }\end{array}$ & Labour & $\begin{array}{l}\text { Lack of Expertise, knowledge } \\
\text { or training }\end{array}$ & Labour \\
\hline $\mathbf{7}$ & $\begin{array}{l}\text { Lack of knowledge and } \\
\text { training on equipment }\end{array}$ & $\begin{array}{l}\text { Equipment } \\
\text { and Tools }\end{array}$ & Inadequate safety policy & Management \\
\hline $\mathbf{8}$ & $\begin{array}{l}\text { Lack of safety eliminating/ } \\
\text { avoiding design }\end{array}$ & Design & $\begin{array}{l}\text { Lack of Management } \\
\text { commitment in contract }\end{array}$ & Contract \\
\hline $\mathbf{9}$ & Unskilled labours & Labour & $\begin{array}{l}\text { Lack of safety eliminating/ } \\
\text { avoiding design }\end{array}$ & Design \\
\hline
\end{tabular}

From the Table 5.2, inadequate safety management policy is the highest ranked causes for the owner group. Unfit equipment, lack of teamwork, not-strict operation procedures in contract, unaware of safety related issue, and lack of personal protective equipment are also considered as a great contributor for occurring fatal accident at construction site based on the owner aspect. The top most critical cause for consultant group is unfit equipment. The consultant group is also point out that unaware of safety related issue, lack of knowledge and training on equipment, improper auditing system, and safety is not considered when design is highly responsible for influencing fatal accident at construction site in Bangladesh.

From the analysis of both table it is figured out that not-strict operation procedures in contract, lack of safety eliminating/ avoiding design, no interest to change the safety culture, unskilled labors, unwilling to spend safety related cost, irregular investigation, lack of expertise- knowledge or training, unfit equipment, inadequate safety policy, ineffective audit and supervision system, and unaware of safety related issue are the most crucial causes for all respondent groups.

\subsection{Ranked of Major Groups of Causes}

Yet above, it is only discussed and analysis of seventy-seven (77) causes but not the major groups of causes of fatal accident at construction site in Bangladesh. In this section, the major fourteen (14) groups are analyzed by the RII and RII based rank. In this section of study table 6.1 is discussed for the rank of major groups of causes.

From Table 6.1 it is revealed that management related causes group is ranked the highest position among all group. So the contribution of this group of influencing accident is more than other groups. The second and third highest ranked groups are consultant related and technology related. This two groups of causes also highly responsible for frequent fatal accident in Bangladeshi construction industry. The lowest ranked group is contract related and the second lowest is cost \& time related causes. Contractor, labor and equipment related factors are also very intensive for influencing fatal accident at construction site in Bangladesh.

Table 6.1: Summary of RII based rank of major groups of passive causes for each groups of respondents

\begin{tabular}{cccccc}
\hline \multirow{2}{*}{ Major Group } & \multicolumn{7}{c}{ Rank } & & \\
\cline { 2 - 6 } & Contractor & Worker & Owner & Consultant & overall \\
\hline Project related & 11 & 12 & 11 & 12 & 11 \\
\hline Site Condition related & 6 & 8 & 10 & 5 & 8 \\
\hline Contract related & 14 & 4 & 9 & 13 & 14 \\
\hline Design related & 9 & 11 & 6 & 11 & 7 \\
\hline Material related & 3 & 5 & 8 & 4 & 10 \\
\hline Cost \& Time related & 13 & 14 & 13 & 14 & 13 \\
\hline
\end{tabular}




\begin{tabular}{cccccc}
\hline Consultant related & 5 & 7 & 2 & 10 & 2 \\
\hline Contractor related & 10 & 2 & 3 & 3 & 5 \\
\hline Labour related & 4 & 6 & 1 & 2 & 4 \\
\hline Owner related & 12 & 13 & 12 & 6 & 12 \\
\hline $\begin{array}{c}\text { Equipment and Tools } \\
\text { related }\end{array}$ & 1 & 1 & 4 & 1 & 6 \\
\hline Management related & 2 & 9 & 5 & 9 & 1 \\
\hline Technology related & 7 & 3 & 7 & 8 & 3 \\
\hline External related & 8 & 10 & 14 & 7 & 9 \\
\hline
\end{tabular}

Table 6.1 shows the RII based rank of major groups of causes according to the feedback of different respondent groups toward the major groups of causes. It shows that equipment and tools related group is hold the highest rank for the contractor, labor and consultant groups. But the owner group is thought that the highest contributing major group is labor related causes. And the second highest contributor group is management related causes for contractor group, contractor related causes for worker group, consultant related causes for owner group, and labour related causes for consultant group. Material, technology and site condition related causes also high ranked for all respondent groups.

The lowest ranked groups of causes for contractor is contract related causes, for labor is cost \& time related causes, for owner is external related causes and for consultant is cost \& time related causes. These are also important for influencing accident but not as much as the high ranked groups of causes.

\subsection{Analysis of Major Group Causes of Accident}

Previously identified seventy seven (77) causes are grouped into fourteen (14) major group. In a group, all the causes are not considered as the same priority for contributing to occurring accidents on construction site. So in this section, it is discussed about the causes and compared them with others causes of same group.

\subsubsection{Project related causes}

The project related group consist of six (6) causes which are influenced construction accident in Bangladeshi construction project. The relative importance index (RII) and rank of project related causes are summarized in Table 2.

From Table 2 it is shown that the type and nature of project is the highest ranked cause among project related causes. It is also listed as top twenty crucial causes of accident in construction project. The second highest ranked cause is very tight project schedule. Most of the respondents considered it as very important causes among the project related causes. And the lowest ranked cause is financial bodies profile (WB, ADP, Government or private). The financial bodies have influence on regulation and work procedure topic but not as much as important than other causes of this major group. Other causes of this group are shown in Table 7 with their RII and rank.

\subsubsection{Site condition related causes}

Site related causes group contain four (4) important causes that responsible for accident in construction project. The relative importance index (RII) and rank of Site condition related causes are summarized and shown in Table 2.

Site related causes are evaluated by the respondent of this study is not so much crucial than other major groups of causes. Among them poor housekeeping is hold the highest position. Respondents thought poor housekeeping and project working environment (light/noise/hot/cold/wet) are mostly important from this group. Project working environment is determined as the second highest ranked and project site conditions 
(exclude equipment, materials, weather) is determined as the third most important cause among this major group. Project site layout/space is hold the lowest ranked in the group.

\subsubsection{Contract related causes}

This group is form with five (5) causes of accident in construction project. This five causes relative important index (RII) and ranked are summarized in Table 2.

Table 2 shows the highest ranked cause of this group is not-strict operation procedures in contract. This cause is determined as the most crucial one which is highly responsible for accident in construction project. The second highest is unclear contract conditions on safety issue. Lack of Management commitment in contract and Type of awarding contract are stand for the third and fourth position based on contribution to occurring accident. Coordination between project participants is the lowest ranked cause determined for this major group of causes.

\subsubsection{Design related causes}

The design related major group is consist of four (4) accident influencing factors in Bangladeshi construction project. Table 2 shows the summary of RII and rank of this major group.

From Table 2 it is clear that among all the causes of the group, lack of safety eliminating/ avoiding design is hold the highest rank for the greatest contribution to occurring accident. It is also determined as $3^{\text {rd }}$ highest ranked cause among 77 other causes based on overall evaluation of respondents. Safety is not consider when design is hold the second highest rank for noticeable contribution to occurring accident. This cause individually ranked stand $17^{\text {th }}$ rank among 77 causes. The $3^{\text {rd }}$ rank cause for this group is design is not constructible. The lowest ranked cause for this group is incomplete and inconsistency of design document which have small influence on accident in construction project.

\subsubsection{Material related causes}

This group is consist of five (5) important causes of accident in construction project in Bangladesh. Table 2 shows the RII based rank among the causes of material related causes group.

Lack of protection in material storage is determined as the highest ranked cause based on respondent's evaluation for this major group. This cause is in the top 20 crucial causes among 77 causes which are mostly responsible for accident. Hazard during transportation and working with toxic/ hazardous materials are stood for $2^{\text {nd }}$ and $3^{\text {rd }}$ highest rank for their impotency of influencing. Lack of knowledge about construction materials is the $4^{\text {th }}$ important cause of accident. And the lowest ranked causes in this major group is lack of protection in material carrying.

\subsubsection{Cost and time related causes}

The major group of cost and time related causes have three cause of accident in Bangladeshi construction project. Table 2 shows the summary of Relative Importance Index (RII) and RII based rank for all causes of this major group.

Short time assign to worker is determined as the highest contributor among this group to occurring accident in construction project. Schedule delays and rework in project is stood for $2^{\text {nd }}$ highest rank in this group. And the lowest ranked cause is cost overrun reduce the safety cost. All the causes of this major group is low ranked respect to overall ranking among 77 causes.

\subsubsection{Consultant related causes}

Consultant related group is consist of six (6) weighted causes of accident in Bangladeshi construction project. In table 2, the summary of RII and RII based rank of the causes under this major group. 
Table 2 indicates the highest ranked cause among the group is irregular investigation. This causes is absolutely very important for accident and it is stood $6^{\text {th }}$ position among the other 77 overall causes according to the respondents rating. The $2^{\text {nd }}$ and $3^{\text {rd }}$ highest ranked cause in this group are unaware of construction safety and lack of management/ leadership skills. No interest to change the safety culture and flexible to contractor/worker on safety issue are also play an important role on the topic of accident in construction project in Bangladesh. And the lowest ranked cause is lack of knowledge and experience.

\subsubsection{Contractor related causes}

This major group is formed with the six (6) intensive causes of accident in construction project. All the causes of this group are summarized in the Table 2 with RII and RII based rank.

Table 2 reveals the highest ranked $\left(1^{\text {st }}\right)$ cause among the group is unaware of safety related issue. This cause is determined the highest contributor to occurring accident in construction project among all other 77 causes. It is also the primary cause of safety hazards and accident around the world. The $2^{\text {nd }}$ highest ranked cause is unwilling to spend safety related cost and it is stood $13^{\text {th }}$ rank among 77 causes based on the respondents rating. Violating BNBC code/ Bangladesh labour law and inaccurate or incomplete schedule are also ranked $4^{\text {th }}$ and $5^{\text {th }}$ in this group. The lowest $\left(6^{\text {th }}\right)$ contributor of this group is lack of skill and experience of site staff and second lowest ranked $\left(5^{\text {th }}\right)$ cause is Reckless action of contractor for contractor related major group.

\subsubsection{Labor related causes}

The labor related causes group is remain nine (9) furious causes of accident in construction project in Bangladesh.

Table 2 indicates that the $1^{\text {st }}$ ranked cause in this group is lack of personal protective equipment. It is also determined as the $2^{\text {nd }}$ highest contributor to the occurring accident among other 77 causes. The second and third highest important causes in this major group are lack of expertise, knowledge or training and unskilled worker. Lack of expertise, knowledge or training is also obtained the $8^{\text {th }}$ rank and unskilled worker is stood for $10^{\text {th }}$ rank among overall 77 causes of accident. The $4^{\text {th }}, 5^{\text {th }}, 6^{\text {th }}$ and $7^{\text {th }}$ rank causes among this group are behavior of worker, over time for labours, lack of collaboration among labours and worker empowerment to make decision. The second lowest $\left(8^{\text {th }}\right)$ ranked cause is poor of education of labours and the lowest $\left(9^{\text {th }}\right)$ ranked is interference with others role. It is clear from the respondent's perspective that this major group is very much responsible for the accident in construction project in Bangladesh.

\subsubsection{Owner related causes}

This major group is consist of five (5) important causes of accident in construction project in Bangladesh. Table 2 shows the Summary of this group with RII and rank of each cause based on respondent's evaluation.

The most contribution is determined from the group is unwilling to pay extra cost for safety. This cause is also stood for the $9^{\text {th }}$ rank position among all 77 causes. The second highest contributor in this group is owner's late response (decision making). The $3^{\text {rd }}$ and $4^{\text {th }}$ ranked causes are lack of owner's emphasis on safety and owner's interference on schedule and process among the owner related major group of causes. The lowest ranked $\left(5^{\text {th }}\right)$ contributor is owner's expectations variation in this group.

\subsubsection{Equipment and Tools related causes}

This major group is consist of six (6) crucial causes of accidents on construction project in Bangladesh. Table 2 shows summary of this group with RII and RII based rank.

From the above table the highest ranked cause in this group is unfit equipment. The second highest ranked cause is lack of knowledge and training on equipment. This two are individually stood for the $4^{\text {th }}$ and $5^{\text {th }}$ rank position among all over 77 causes of accident. Poor equipment maintenance and improper use of 
equipment are two important causes in this group that have great influence on occurring accident. And the lowest ranked $\left(6^{\text {th }}\right)$ and second lowest $\left(5^{\text {th }}\right)$ cause is unused of modern equipment and high cost of advanced equipment and tools for this major group. This major group is very high ranked among other major group. So it is important to take a serious look after this group of causes.

\subsubsection{Management related causes}

Management related major group is formed with eight (8) causes of accident in construction project in Bangladesh. Table 2 shows the RII and rank of causes under this major group.

The highest ranked $\left(1^{\text {st }}\right)$ cause in the group is inadequate safety policy and the second highest ranked $\left(2^{\text {nd }}\right)$ is lack of effective project supervision. The $3^{\text {rd }}$ and $4^{\text {th }}$ ranked causes in among this group are lack of teamwork and lack of information flow. They are also accused greatly for influencing accident. Other important causes in this group are by ranked improper auditing system $\left(5^{\text {th }}\right)$, lack of effective communication $\left(6^{\text {th }}\right)$ and poor organization structure $\left(7^{\text {th }}\right)$. And the lowest ranked $\left(8^{\text {th }}\right)$ cause in this major is lack of technique guide. This major group is one of the most responsible group of influencing accident in construction project in Bangladesh.

\subsubsection{Technology related causes}

The technology related major group of causes is consist of six (6) vital causes. Table 2 shows the summary of this major group of causes with RII and their relative rank.

Table 2 indicates that the highest ranked $\left(1^{\text {st }}\right)$ cause in this group is unused of safety control system for this major group. Lack of implementation of BIM and lack of innovation technology are stood for the $2^{\text {nd }}$ and $3^{\text {rd }}$ position based on RII rank among the causes of this group. Unaware to advanced technology for safety $\left(4^{\text {th }}\right)$ and lack of implement safety control sensor technology $\left(5^{\text {th }}\right)$ are also important in this major group. And the lowest ranked $\left(6^{\text {th }}\right)$ cause for this group is unused of schedule system.

\subsubsection{External related causes}

External related major group of causes is formed with four (4) intensive factors that influencing the accident in construction project in Bangladesh. Table 2 shows the summary of the RII and RII based rank of the causes of this major group.

The highest ranked $\left(1^{\text {st }}\right)$ cause is bad weather and the second highest ranked $\left(2^{\text {nd }}\right)$ cause is nature of the construction for the external related major group of causes. The lowest ranked $\left(4^{\text {th }}\right)$ cause is act of God and second lowest $\left(3^{\text {rd }}\right)$ cause is external obstacle/ barrier. This group is not very much responsible but responsible for occurring accident in construction project.

\section{Discussion and Conclusion}

A statistical data analysis based method is used for the design of the questionnaire for this study. The questionnaire-based survey was used to elicit the attitude of workers, owners, consultants, and contractors towards causes of accident in construction project in Bangladesh. 147 questionnaires were distributed as follows: 44 to workers, 27 to owners, 41 to consultants and 35 to contractors. 108 questionnaires $(73.5 \%)$ were returned as follows: 32 from workers, 23 from owners, 28 from consultants, and 25 from contractors as respondents. The respondents were asked to evaluate the level of significant of each of the 77 causes of accident in construction project in Bangladesh according to seven point Likert Scale.

For the analysis of causes of accident in construction project in Bangladesh, a questionnaire was designed with 77 causes under 14 major groups of causes. These 14 major groups are (1) Project related, (2) Site Condition related, (3) Contract related, (4) Design related, (5) Material related, (6) Cost \& Time related, (7) Consultant related, (8) Contractor related, (9) Labour related, (10) Owner related, (11) Equipment and Tools related, (12) Management related, (13) Technology related, and (14) External related causes. Among 
the 77 causes, contractor unaware of safety related issue is placed highest rank, lack of personal protective equipment of worker is placed second highest, lack of safety eliminating/ avoiding design and unfit equipment use in the construction work are third and fourth highest rank causes for all groups of respondents. Lack of knowledge and training on equipment, irregular investigation by consultant, inadequate safety policy adopted by management and lack of expertise, knowledge or training of worker are also high raked and very impactful causes.

The study represents that the highest ranked causes for worker group is not-strict operation procedures in contract, for contractor group is lack of personal protective equipment of labour, for owner group is inadequate safety management policy and for consultant group is unfit equipment. The second highest ranked causes for worker is lack of safety eliminating/ avoiding design, for contractor group is lack of knowledge and training on equipment, for owner group is unfit equipment and for consultant group is unaware of safety related issue. It is also revealed that not-strict operation procedures in contract, lack of safety eliminating/ avoiding design, no interest to change the safety culture, unskilled labors, unwilling to spend safety related cost, irregular investigation, lack of expertise, knowledge or training, unfit equipment, inadequate safety policy, ineffective audit and supervision system and unaware of safety related issue are the most crucial for each group of respondents of accident in construction project.

Bangladesh is a very accident prone area in the construction sector. This study reveals the causes behind the huge amount of accidents. To reduce the accident rate and design an effective safety program, respective authorities could use this study as a guideline or information source. It helps to understand about the background of occurring accident and the responsible factors.

\section{References}

1. Sousa, V., N.M. Almeida, and L.A. Dias, Risk-based management of occupational safety and health in the construction industry-Part 1: Background knowledge. Safety science, 2014. 66: p. 75-86.

2. Biswas, G., A. Bhattacharya, and R. Bhattacharya, Occupational health status of construction workers: A review. International Journal of Medical Science and Public Health, 2017. 6(4): p. 669675.

3. Islam, M.S., I. Razwanul, and M.T. Mahmud, Safety Practices and Causes of Fatality in Building Construction Projects: A Case Study for Bangladesh. Jordan Journal of Civil Engineering, 2017. 11(2).

4. Ahmed, S., M.H.R. Sobuz, and M.I. Haque. ACCIDENTS ON CONSTRUCTION SITES IN BANGLADESH: A REVIEW. in 4th International Conference on Civil Engineering for Sustainable Development (ICCESD 2018). 2018. 9 11 February 2018, KUET, Khulna, Bangladesh.

5. Ahemd, S. and I. Bashar, Analysis of accident on construction site in bangladesh: A construction safety management issue, in Building Engineering and Construction Management. 2018, Khulna Khulna University of Engineering and Technology: Khulna, Bangladesh.

6. HSE, U., HSE principles for cost benefit analysis (CBA) in support of ALARP decisions. 2017.

7. Muralidhar, V., M.F. Ahasan, and A.M. Khan, Parenchymal asbestosis due to primary asbestos exposure among ship-breaking workers: report of the first cases from Bangladesh. BMJ case reports, 2017. 2017: p. bcr-2017-222154.

8. Sadarangani, S.P., P.L. Lim, and S. Vasoo, Infectious diseases and migrant worker health in Singapore: a receiving country's perspective. Journal of travel medicine, 2017. 24(4).

9. Kearney, G.D., J.A.G. Balanay, and A.J. Mannarino, Safety behavior and work safety climate among landscaping and groundskeeping workers in North Carolina: A pilot study. Work, 2017. 56(1): p. 45-53.

10. Aziz, R.F. and A.A. Abdel-Hakam, Exploring delay causes of road construction projects in Egypt. Alexandria Engineering Journal, 2016. 55(2): p. 1515-1539.

11. Burr, A., Delay and disruption in construction contracts. 2016: CRC Press. 
12. Larsen, J.K., et al., Factors affecting schedule delay, cost overrun, and quality level in public construction projects. Journal of Management in Engineering, 2015. 32(1): p. 04015032.

13. Rumane, A.R., Quality management in construction projects. 2016: CRC Press.

14. Zeng, S.X., C.M. Tam, and V.W. Tam, Integrating safety, environmental and quality risks for project management using a FMEA method. Engineering Economics, 2015. 66(1).

15. Hiyassat, M.A., M.A. Hiyari, and G.J. Sweis, Factors affecting construction labour productivity: $a$ case study of Jordan. International Journal of Construction Management, 2016. 16(2): p. 138-149.

16. Sveikauskas, L., et al., Productivity growth in construction. Journal of Construction Engineering and Management, 2016. 142(10): p. 04016045.

17. Jadhav, P., D. Desai, and A. Gupta, Analysis of Construction Cost Overrun Causes-Contractor's View. Imperial Journal of Interdisciplinary Research, 2016. 2(8).

18. Shehu, Z., et al., Cost overrun in the Malaysian construction industry projects: A deeper insight. International Journal of Project Management, 2014. 32(8): p. 1471-1480.

19. Gunduz, M., M.T. Birgonul, and M. Ozdemir, Fuzzy structural equation model to assess construction site safety performance. Journal of Construction Engineering and Management, 2016. 143(4): p. 04016112.

20. Leung, M.-Y., Q. Liang, and P. Olomolaiye, Impact of job stressors and stress on the safety behavior and accidents of construction workers. Journal of Management in Engineering, 2015. 32(1): p. 04015019.

21. Albert, A. and M.R. Hallowell. Hazard recognition methods in the construction industry. in Construction Research Congress 2012: Construction Challenges in a Flat World. 2012.

22. Cheng, C.-W. and T.-C. Wu, An investigation and analysis of major accidents involving foreign workers in Taiwan's manufacture and construction industries. Safety science, 2013. 57: p. 223235.

23. Hamid, A.R.A., M.Z.A. Majid, and B. Singh, Causes of accidents at construction sites. Malaysian journal of civil engineering, 2008. 20(2): p. 242-259.

24. Priyadarshani, K., G. Karunasena, and S. Jayasuriya, Construction safety assessment framework for developing countries: a case study of Sri Lanka. Journal of Construction in Developing Countries, 2013. 18(1): p. 33.

25. Al-Kaabi, N. and F. Hadipriono, Construction safety performance in the United Arab Emirates. Civil Engineering and Environmental Systems, 2003. 20(3): p. 197-212.

26. Uduakobonge E. Udo, E.E.U.a.C.F.A., Effect of Lack of Adequate Attention to Safety Measures on Construction Sites in Akwa Ibom State, Nigeria. Journal of Earth Sciences and Geotechnical Engineering, 2016. 6(1): p. 113-121.

27. Haslam, R.A., Hide, S.A., Gibb, A.G.F., Contributing factors in construction accidents. Applied Ergonomics, 2005. 36(4): p. 401-415.

28. Ogwueleka, A.C., A Review of Safety and Quality Issues in the Construction Industry. KICEM Journal of Construction Engineering and Project Management, 2013. 3(3): p. 42-48.

29. Hamid, A.R.A., B. Singh, and A.B. Arzmi. CONSTRUCTION PROJECT MANAGER WAYS TO COPE WITH STRESS AT WORKPLACE. in SEPKA 2014: National Seminar on Civil Engineering Research, Training Center, UTM Skudai. FKA-PGSS FKA-UTM. 2014.

30. Ogwueleka, A.C., A review of safety and quality issues in the construction industry. Journal of Construction Engineering and Project Management, 2013. 3(3): p. 42-48.

31. Le-Hoai, L., Y.D. Lee, and J.Y. Lee, Delay and cost overruns in Vietnam large construction projects: A comparison with other selected countries. KSCE journal of civil engineering, 2008. 12(6): p. 367377. 